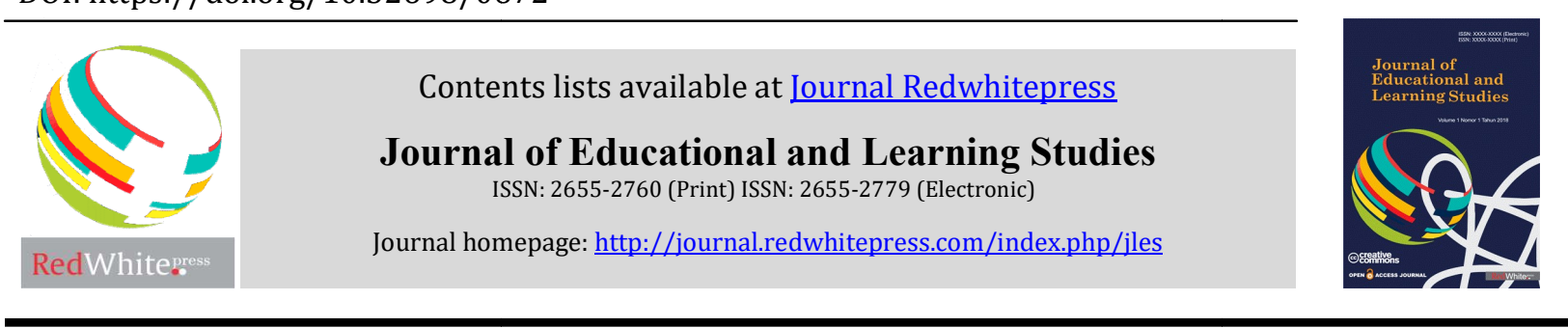

\title{
Elderly Self-Acceptance Based on Gender and Residence and Its Implications to the Guidance and Counseling Services
}

\author{
Alvi Rahmi ${ }^{1}$, Daharnis ${ }^{1}$, Syahniar ${ }^{1}$ \\ ${ }^{1}$ Universitas Negeri Padang
}

\begin{tabular}{|c|c|}
\hline Article Info & ABSTRACT \\
\hline Article history: & This study was conducted based on the lamentations of old people about the \\
\hline Received Dec 30 $30^{\text {th }}, 2018$ & existence of themselves. They cannot accept their changes both physical and \\
\hline Revised Jul $25^{\text {th }}, 2019$ & elderly in terms of gender and place of residence. The study sample consisted \\
\hline Accepted Aug 30 $30^{\text {th }}, 2019$ & $\begin{array}{l}\text { of } 116 \text { elderly people, } 67 \text { elderly people who lived at home and } 49 \text { elderly } \\
\text { people who lived in Tresna Werdha Kasih Sayang Ibu Nursing Home in }\end{array}$ \\
\hline Keyword: & $\begin{array}{l}\text { Batusangkar. The instrument used was the elderly self-acceptance } \\
\text { questionnaire with reliability of } 0.840 \text {. The results of this study are the self- }\end{array}$ \\
\hline Self-Acceptance & acceptance of the elderly differs significantly in terms of gender and place of \\
\hline Elderly & nce and there is an interaction between gender and residence in \\
\hline Gender & aining the self-acceptance of the elderly. \\
\hline
\end{tabular}

(C) 2019 The Authors. Published by Redwhitepress.

Residence

\section{Corresponding Author:}

Alvi Rahmi

Universitas Negeri Padang

Email: alvirahmi74@gmail.com

\section{Introduction}

Elderly is a phase that is traversed by humans who live long. Santrock (2012) suggests that the elderly phase begins in the 60 s or 70 s and lasts until death. Similarly, Hurlock (2004) explains that individuals who are in the elderly phase are those aged 60 years and over. Changes that occur in the elderly phase depend on previous developments, and personal lifestyle, such as mental attitude, social relations, mental and physical activities, diet, amount of time, and regulation of rest periods. The elderly period is characterized by changes experienced by the elderly, including the growth of gray hair, skin that begins to wrinkle, weight loss, the date of the teeth so that it has difficulty eating. In addition, there are also changes that affect the psychological life of the elderly, such as feelings of exclusion, no longer needed, inhumanity to accept new reality, and changes related to the interaction of the elderly with the social environment (Munandar, 2001).

Changes that occur in elderly demand the elderly to be able to adapt themselves with the tasks following their development. One of the things that must be owned so that the elderly can adapt themselves is the ability to accept themselves and the environment well. For many people, being unaccepted by the environment is a part of life (Plexico, Erath, Shores, \& Burrus, 2019). Hurlock (2004) explains that there are two types of individual attitudes: those who are able to accept changes with deep awareness and those who are unable to accept changes in their old age. Monks, F. J., \& Knoers (2013) also explain that the elderly who can accept their reality do not reject and complain about their shortcomings, which means they have been able to achieve integrity. Elderly people who are not able to accept their existence are called despair (De Nardo, Gabel, Tetnowski, \& Swartz, 2016), and their characteristics include feeling deep fear, feeling meaningless life arising from their resentment, and rejection of their environment. Those characteristics are essentially feelings 
of hopelessness and self-rejection. Individuals who despair cannot feel happiness, because one of the components of happiness for the elderly is self-acceptance.

Self-acceptance is a level of individual awareness about personal characteristics and the willingness to live with such conditions (Hurlock, 2004). Individuals with good self-acceptance feel that certain characteristics possessed are inseparable parts of themselves, which subsequently grow as gifts. Such individuals feel everything they have is something pleasant, so that they have desire to continue to enjoy life. In addition, they can gracefully accept any changes related to the aging process. Hurlock (2004) explains the factors that influence the self-acceptance of the elderly include understanding of themselves, the existence of things that are realistic, the absence of obstacles in the environment, pleasant attitudes of community members, the absence of severe emotional disturbances, the influence of success experienced, identification with people who have good adaptation, broad self-perspective, broad parenting and self-concept. The better the fulfillment of these factors, the greater the chance of the elderly to be able to accept themselves well and positively.

Self-acceptance in terms of gender has several different characteristics. According to Hurlock (2004) male and female elderly people have different self-acceptance, which is caused by the rate of changes, attitudes, views, functions, positions, duties, responsibilities, and cultures. Elderly men and elderly women have different views about life in their old age. The research conducted by Ardhistia (2015) found that the selfacceptance of elderly women was higher than that of elderly men. Such difference was caused by various factors and habits and the different perspectives between men and women. The research by Saputra, Daharnis, \& Yarmis (2017) found that the task accomplishment of the development of elderly men in Dharmasraya was in the moderate category and the achievement of tasks in the development of elderly women in Dharmasraya was in the high category. One of the factors that distinguishes the achievement of this development task is selfacceptance.

Another factor that also influences the self-acceptance of the elderly is the physical environment. The physical environment that is intended is a place to live. There are elderly who live with their families (wives, husbands, children and grandchildren) and those who live in social institutions or nursing homes. Elderly people who live with their families should have better life qualities than those who live in nursing homes, because the elderly who live with the family do not only get physical care, but also get affection, togetherness, interaction or good communication, and receive assistance from the family, all of which are functions of the family (Johnson \& Leny, 2010). Based on the observations to ten elderly men and ten elderly women in Kenagarian Balimbing Jorong Balimbing, Rambatan Subdistrict, Tanah Datar District on March 15, 2018, , it can be concluded that the elderly showed a lack of self-acceptance. The results of the interview with one of the officers in Tresna Werdha Kasih Sayang Ibu Nursing Home in Batusangkar on April 21, 2018 showed that the elderly staying in Tresna Werdha Kasih Sayang Ibu Nursing Home were mostly troubled and needed psychological treatment. Psychological problems of the elderly were generally related to family affairs.

Looking at the phenomena that occur and refer to the factors that influence the self-acceptance of the elderly, various forms of guidance and counseling services are needed for the elderly to be able to accept themselves well and positively. Guidance and Counseling are efforts to provide assistance from counselors to clients to empower clients in making decisions and making them happen (Prayitno, 2012). Self-acceptance is one of the independence characteristics that must be possessed by each individual in order to realize effective daily life, including by the elderly. For this reason, it is necessary to have a more in-depth study of elderly selfacceptance in terms of gender and place of residence so that guidance and counseling services can be carried out effectively and efficiently.

\section{Methods}

This research uses a quantitative approach with a descriptive comparative design. The study population was 165 elderly people at Tresna Werdha Kasih Sayang Ibu dan Lansia Nursing Home in Batusangkar at Jorong Balimbing, Balari Nagari, Rambat Subdistrict, Tanah Datar District, West Sumatra. The sample in this study was 116 elderly people selected by using a proportional random sampling technique. The instrument used in this study was the scale of Elderly Self-Acceptance. The reliability test results of the achievement of the task of developing the elderly were 0.840 . To find out the differences in the self-acceptance of the elderly in terms of gender and place of residence analyzed, variance analysis technique (ANOVA) was used. The data analysis was assisted by using Statistical Product and Service Solution (SPSS) program of 20.0 version.

\section{Result and Discussion}

The discussion in the results of this study includes (1) the description of elderly self-acceptance in terms of gender and place of residence, (2) the description of elderly self-acceptance in terms of place of 
residence in the nursing home and at home with family, and (3) the interaction between gender and place of residence in explaining the self-acceptance of the elderly.

\section{Result}

Description of elderly self-acceptance in terms of gender and place of residence

Table 1. Description of the Elderly Self -Acceptance Based on Gender and Residence $(\mathrm{n}=116)$

\begin{tabular}{|c|c|c|c|c|c|c|}
\hline \multicolumn{7}{|c|}{ Elderly Self-Acceptance } \\
\hline Gender (A) & $\begin{array}{l}\text { Residence } \\
\text { (B) }\end{array}$ & $\mathbf{N}$ & Average & $\begin{array}{c}\text { Percentage } \\
(\%)\end{array}$ & SD & Category \\
\hline \multirow[t]{3}{*}{ Male (A1) } & $\begin{array}{l}\text { Tresna Werdha } \\
\text { Nursing Home (B1) }\end{array}$ & 29 & 103.59 & 54.50 & 17.628 & Moderate \\
\hline & $\begin{array}{l}\text { At Home with Family } \\
\text { (B2) }\end{array}$ & 39 & 125.59 & 66.10 & 9.312 & Moderate \\
\hline & Overall male elderly & 68 & 116.21 & 61.16 & 17.299 & Moderate \\
\hline \multirow[t]{3}{*}{ Female (A2) } & $\begin{array}{l}\text { Werdha Nursing Home } \\
\text { (B1) }\end{array}$ & 20 & 116.70 & 61.42 & 13.635 & Moderate \\
\hline & $\begin{array}{l}\text { At home with family } \\
\text { (B2) }\end{array}$ & 28 & 128.14 & 67.44 & 9.156 & Moderate \\
\hline & Overall female elderly & 48 & 123.38 & 64.90 & 12.483 & Moderate \\
\hline \multicolumn{2}{|c|}{ Tresna Werdha Nursing Home } & 49 & 108.94 & 57.34 & 17.241 & Moderate \\
\hline \multicolumn{2}{|c|}{ At home with family } & 67 & 126.66 & 66.66 & 9.265 & Moderate \\
\hline \multicolumn{2}{|r|}{ TOTAL } & 116 & 119.17 & 62.72 & 15.830 & Moderate \\
\hline
\end{tabular}

Based on Table 1, it can be understood that the overall self-acceptance is in the medium category. The highest average self-acceptance of the elderly is female who live in homes with families, with an average score of 128.14 or can be subjected to a score of $67.44 \%$ of the ideal score, and the average self-acceptance of the lowest elderly is male who live in Tresna Werdha Nursing Home, with an average score of 103.59 or can be subjected to $54.50 \%$ of ideal score.

Table 2. Summary of Factorial 2-way ANOVA (2x2)

\begin{tabular}{|c|c|c|c|c|c|c|}
\hline Variant Sources & $\mathbf{J k}$ & Dk & Rk & $\mathbf{F}$ & Sig. & Interpretation \\
\hline Male and Female Elderly & 1683.045 & 1 & 1683.045 & 10.595 & 0.002 & Significant \\
\hline $\begin{array}{c}\text { Elderly who lives at } \\
\text { Tresna Werdha Nursing } \\
\text { Home and at home with } \\
\text { the family }\end{array}$ & 7670.571 & 1 & 7670.571 & 48.286 & 0.000 & Significant \\
\hline $\begin{array}{l}\text { Interaction of the gender } \\
\text { and residence }\end{array}$ & 764.738 & 1 & 764.738 & 4.814 & 0.030 & Significant \\
\hline
\end{tabular}

The data presented in Table 2 show that there are significant differences in elderly self-acceptance in terms of gender, with sig $0.002<0.05$, there are significant differences in elderly self-acceptance in terms of place of residence, with sig $0.000<0.05$ and there are interactions between gender and place of residence in explaining self-acceptance, with sig $0.002<0.05$.

\section{Discussion}

The research findings indicate that the elderly self-acceptance in terms of gender and place of residence as a whole is in the moderate category (S), meaning that overall the elderly still need to increase their acceptance so they can live well and happily.

The results of the study illustrate that there are significant differences in the self-acceptance of the elderly in terms of gender, meaning that the elderly men and women have differences in accepting what happened to them (Jiang, Wang, Hu, \& Wang, 2019). Setiti (2007) explains that the ideology of gender roles is a normative belief about what men and women should be, what each should do and so on. Beliefs that exist in the community about what women are and what men are like will certainly influence parenting and other aspects of men and women (de Nardo et al., 2016). Gender is one of the person's considerations in behaving. Individuals tend to behave according to their roles, duties and responsibilities according to their gender. This is in accordance with the opinion of Berry, Poortinga, Segall, \& Dasen (2002) who explain that there are differences in individual behavior based on gender in each community. This is one of the things that affects individual differences in terms of self-acceptance. 
The findings of this study are in line with the research of Carson \& Langer (2006) who found that the quality of life of elderly people is influenced by gender, and women have a better quality of life than men. This study explained that one of the factors affecting the quality of life of the elderly is how the elderly are able to accept and adapt to the changes that occur to them, along with their increasing age. Deeks and McCabe (2004) found that there were significant differences in terms of self-acceptance between elderly men and elderly women who were menopausal. This is caused by various factors, one of which is that men and women are different in accepting the reactions of changes that occur to them because of different feelings. In addition, men who used to work for the family's needs fulfillment, but due to their old age have to quit working, usually lose their pride when they live with their children, grandchildren, and daughter-in-law or even in Nursing Home usually lose their pride because they cannot fulfill the family's needs anymore (Woodford, Kulick, Sinco, \& Hong, 2014).

This makes elderly man rebel or unable to accept these feelings. Meanwhile, women in old age feel more useful, because there are still many things that can be done, such as household work, caring for a retired husband, stopping work or helping children and grandchildren. Ryff \& Singer (2008) suggested "that women of all ages consistently rate themselves higher on positive relations with others than do men, and that women tend to be higher than men on personal growth". This means that women see themselves more valuable than men when they are older and have better personality growth than men. In addition to the things described above, there is one important thing that causes differences in the self-acceptance of elderly men and women, i.e. cultural background. Culture is a matter that greatly influences individual behavior, including the path that will be chosen, expectations, processes, and use of information by humans (Cheung \& $\mathrm{Ng}$, 2019). If studied from the culture of the research place, it is assumed that women have dominant role in Minangkabau culture due to its matrilineal system in which all kinds of family rights and obligations are calculated through the descendants of the female elderly.

The matrilineal system applied in Minangkabau society has placed women in a central position and they are described as having a stable and strong position compared to Minangkabau men (Abadini, 2009). Women are also likened to the Minangkabaunese terms amban puruak pagangan kunci and amban puruakaluang bunian, meaning the ruler of the household key holder and the ruler of the holder of the inheritance. The parable shows the magnitude of the role of women in Minangkabau culture which requires them to be strong people with such a large role. Minangkabau custom recognizes the existence of biological nature, meaning that men and women have different characteristics but such difference does not mean that one is higher than the other, each has a position and responsibility (Atmazaki, 2007). The position and responsibility are the factors that lead to the differences in self-acceptance of the elderly. This is in line with the opinion of Hurlock (2004) who states that the older a person is, the less things he can do with the environment. Hawari (1999) states in broad outline the differences between women and men can be mentioned as follows, (1) in dealing with various problems women are more intuitive than men, women's intuition is far stronger than men who express ratio, (2) women have better adaptability than men, (3) in terms of understanding "love" women are more focused on the psychological view point, while men are more on biological view point, (4) women like concrete and small things, unlike men who prefer things that are abstract and global in nature. Kristanto (2016)found a significant difference in the level of gratitude between men and women, where the level of gratitude for women is higher than for men. Kashdan, Mishra, Breen, \& Froh (2009)suggest that gender differences in the prevalence of gratitude arise from differences in the way men and women judge the events they experience. Gratitude is preceded by favorable judgments about the value or benefits received (Wood, Maltby, Stewart, Linley, \& Joseph, 2008). Compared with men, specifically women tend to be more concerned with interpersonal relationships and social care (Döring et al., 2015) who demand to act more positively than men, this makes women enjoy life experiences more that allow increasing the frequency of gratitude and self-acceptance.

The results of data analysis showed that there was a significant difference between the self-acceptance of the elderly living in Tresna Werdha Nursing Home and the elderly who lived at home with their families. Elderly people who live at homes with families have an average score higher than the elderly who live in Tresna Werdha Nursing Home. The elderly who live at Tresna Werdha Nursing Home feel unable to act according to what they want. In addition, they also feel unable to gather with the people they care about and miss the things that are in their family environment, both with children and grandchildren. Moreover, most of the elderly people who live in Tresna Werdha Nursing Home are not due to their own volition, which leads them to feel worthless and unable to accept the conditions. As a result, they tend to feel lonely.

On the other hand, elderly people who live at home with their families feel more cared for by the family environment, feel valued, they feel that life in the past and present is better than others, they deserve to be loved and love, they do not regret their lives and they do not feel ignored. Ryff \& Singer (2008) found that elderly people living in homes with families and elderly people living in Nursing Homes have different psychological well being. Many aspects affect these differences, one of which is self-acceptance. This is related 
to how the elderly feel accepted by the family, although it is possible that there is a mismatch with the children, wife or daughter-in-law.

Elderly people feel they really need support from the family. In the elderly who feel they are not well received by family members, it will be difficult to accept themselves and feel happy. This is because there is a significant relationship between family support and the quality of life of the elderly. This is evidenced by the results of Widya's (2016) research that found differences in the quality of life between the elderly living in Tresna Werdha Nursing Home and the elderly living at home with their families, seen in four components, namely physical, psychological, independence, and individual relationships with the environment. Elderly people who are at home are influenced by family and community support. The support from family and community will not make the elderly experience negative changes to their lives. In other words, if the support from family and community to the elderly is good enough, it will make them experience positive changes in their lives. Such support will certainly affect the self-acceptance of the elderly (Potter, PA, \& Perry, 2005).

Related to the findings elaborated above, Carod-Artal, Egido, González, and Varela de Seijas (2011) found that there was a different quality of life between the elderly who had a stroke treated by the family at home and the elderly who did not live with their families. The first indication that supports this quality of life is self-acceptance, i.e. how the elderly perceive events and changes that occur to them as something that must be accepted and lived as it is. Ramdani, Daharnis, \& Syahniar (2015) found that there was a contribution of family support to the life satisfaction of the elderly, meaning that the higher the family support, the higher the life satisfaction that would be achieved by the elderly.

Setiti (2007) examines the expectations of the elderly to their relatives, and the result is that the elderly want a sincere and reasonable service or support from their family and closest relatives. The relatives keep listening to and undergoing advice from the elderly and any differences are conveyed well without offending. The expectations of other elderly people in the process of dying need to be responded by the family or the orphanage. This is important to protect the elderly from anxiety and fear. The elderly self-acceptance is also influenced by their adaptation to the changes that occur to them. This related to how can individuals are able to adapt themselves with their condition by behaving according to their current age, abilities and circumstances. One of the studies that explains such phenomenon is Aleydrus' (2014) study which found that there were differences in adaptation between the elderly living in the "Pangesti" Nursing Home and those who lived with family in Lawang Subdistrict, where the elderly who lived with their families were better able to adapt because they can adapt well and accept the reality of life according to the development of their age. The results of the study also found that there was an interaction between gender and place of residence in explaining the self-acceptance of the elderly. This is in accordance with what was stated by Hurlock (2004) that aging is influenced by people differently, people grow old differently because they have different inherent traits, socioeconomics, culture, gender, place of residence and educational background. Differences are seen among people who have the same sex, and are more evident when men are compared to women because aging occurs at different rates in each sex.

Family support is also one of the most important factors in determining the self-acceptance of the elderly. The better family support, the better the elderly will be in responding to events that occur to them (Dayton, Saengtienchai, Kespichayawattana, \& Aungsuroch, 2001).

\section{Conclusion}

Based on the results of the research, it is concluded that there are differences in self-acceptance of elderly men and women, there are differences in self-acceptance of elderly who live at home with families and elderly people living in Tresna Werdha Kasih Sayang Ibu Nursing Home, and there is interaction between gender and place of residence in explaining the elderly's self-acceptance. This can be seen from the selfacceptance scores which illustrate the self-acceptance of elderly women who live at homes with families has the highest score and the self-acceptance of elderly men who live in Tresna Werdha Kasih Sayang Ibu Nursing Home has the lowest score.

\section{References}

Abadini, D. (2009). Gambaran Fear of Success pada Wanita Etnis Minangkabau yang Bekerja di Jakarta. Graduate Program of Psichology at Unika Atma Jaya.

Aleydrus. (2014). Perbedaan Penyesuaian Diri Pada Lansia Yang Tinggal di Panti Werdha "Pangesti" Lawang Dengan Lansia yang Tinggal Bersama Keluarga di Kecamatan Lawang Kabupaten Malang. Psikovidya, 18, 561-565.

Ardhistia, S. (2015). Perbedaan Penerimaan Diri antara Lansia yang Tinggal di Panti Wreda Berdasarkan Keputusan Sendiri dan Bukan Berdasarkan Keputusan Sendiri. Universitas Sanata Dharma Yogyakarta. 
Atmazaki. (2007). Dinamika Gender dalam Konteks Adat dan Agama. Padang: UNP Press.

Berry, J. W., Poortinga, Y. H., Segall, M. H., \& Dasen, P. R. (2002). Cross-cultural psychology, 1-15.

Carod-Artal, J., Egido, J. A., González, J. L., \& Varela de Seijas, E. (2011). Quality of Life Among Stroke Survivors Evaluated 1 Year After Stroke. Stroke, 31(12), 2995-3000. https://doi.org/10.1161/01.str.31.12.2995.

Carson, S. H., \& Langer, E. J. (2006). Mindfulness and self-acceptance. Journal of Rational - Emotive and Cognitive - Behavior Therapy, 24(1), 29-43. https://doi.org/10.1007/s10942-006-0022-5.

Cheung, R. Y. M., \& Ng, M. C. Y. (2019). Mindfulness and Symptoms of Depression and Anxiety: the Underlying Roles of Awareness, Acceptance, Impulse Control, and Emotion Regulation. Mindfulness, 10(6), 1124-1135. https://doi.org/10.1007/s12671-018-1069-y.

Dayton, B., Saengtienchai, C., Kespichayawattana, J., \& Aungsuroch, Y. (2001). Psychological well-being Asian style: The perspective of Thai elders. Journal of Cross-Cultural Gerontology, 16(3), $283-302$. https://doi.org/10.1023/A:1011984017317.

Deeks, A. A., \& McCabe, M. P. (2004). Well-being and menopause: An investigation of purpose in life, selfacceptance and social role in premenopausal, perimenopausal and postmenopausal women. Quality of Life Research, 13(2), 389-398. https://doi.org/10.1023/B:QURE.0000018506.33706.05.

De Nardo, T., Gabel, R. M., Tetnowski, J. A., \& Swartz, E. R. (2016). Self-acceptance of stuttering: A preliminary study. Journal of Communication Disorders, $60,27-38$. https://doi.org/10.1016/j.jcomdis.2016.02.003.

Döring, A. K., Schwartz, S. H., Cieciuch, J., Groenen, P. J. F., Glatzel, V., Harasimczuk, J., ... Bilsky, W. (2015). Cross-cultural evidence of value structures and priorities in childhood. British Journal of Psychology, 106(4), 675-699. https://doi.org/10.1111/bjop.12116.

Hawari, D. (1999). Al Qur'an ilmu kedokteran jiwa dan kesehatan jiwa. Yogyakarta: Dana Bhakti Frima Yasa.

Hurlock, E. . (2004). Psikologi Perkembangan: Suatu Pendekatan Sepanjang Rentang Kehidupan (Edisi Kelima). (Istiwidayanti \& Soedjarwo, Eds.). Jakarta: Erlangga.

Johnson, \& Leny, R. (2010). Keperawatan Keluarga: plus Contoh Askep Keluarga. Yogyakarta: Nuha Medika.

Jiang, Z., Wang, Y., Hu, X., \& Wang, Z. (2019). Open Workplace Climate and LGB Employees' Psychological Experiences: The Roles of Self-Concealment and Self-Acceptance. Journal of Employment Counseling, 56(1), 2-19. https://doi.org/10.1002/joec.12099.

Kashdan, T. B., Mishra, A., Breen, W. E., \& Froh, J. J. (2009). Gender differences in gratitude: Examining appraisals, narratives, the willingness to express emotions, and changes in psychological needs. Journal of Personality, 77(3), 691-730. https://doi.org/10.1111/j.1467-6494.2009.00562.x.

Kristanto, E. (2016). Perbedaan Tingkat Kebersyukuran pada Laki-laki dan Perempuan. Psychology \& Humanity, 128-134.

Monks, F. J., \& Knoers, A. M. P. (2013). Psikologi Perkembangan: Pengantar dalam berbagai bagiannya. Yogyakarta: Gajah Mada University Press.

Munandar. (2001). Bunga Rampai Psikologi Perkembangan dari Bayi sampai dengan Lanjut Usia. Jakarta: Universitas Indonesia Press.

Plexico, L. W., Erath, S., Shores, H., \& Burrus, E. (2019). Self-acceptance, resilience, coping and satisfaction of life in people who stutter. Journal of Fluency Disorders, 59(October 2018), 52-63. https://doi.org/10.1016/j.jfludis.2018.10.004.

Potter, P.A., \&Perry, A. . (2005). Basic Nursing (6rdEd). Australia: St. Louis Mosby Elsevier.

Prayitno. (2012). Konseling untuk Semua. In SIK-MALINDO 2. Padang: Jurusan Bimbingan dan Konseling Fakultas Ilmu Pendidikan Universitas Negeri Padang.

Ramdani, Daharnis, \& Syahniar. (2015). Kontribusi Kecerdasan Spiritual dan Dukungan Keluarga terhadap Kepuasan Hidup Lansia serta Implikasinya dalam Layanan Bimbingan dan Konseling. Universitas Negeri Padang.

Ryff, C. D., \& Singer, B. H. (2008). Know thyself and become what you are: A eudaimonic approach to psychological well-being. Journal of Happiness Studies, 9(1), 13-39. https://doi.org/10.1007/s10902-0069019-0. 
Santrock. (2012). Life Span Development: Perkembangan Masa Hidup. Jakarta: Erlangga.

Saputra, R., Daharnis, \& Yarmis. (2017). Ketercapaian Tugas Perkembangan Usia Lanjut ditinjau dari Jenis Kelamin dan Latar Belakang Budaya serta Implikasinya pada Bimbingan dan Konseling. Universitas Negeri Padang.

Setiti, S. G. (2007). Pelayanan Lanjut Usia Berbasis Kekerabatan (Studi Kasus Pada Lima Wilayah Di Indonesia) 1. Puslitbang Kesos, 153-167.

Widya. (2016). Perbedaan Kualitas Hidup antara Lansia yang Tinggal di Keluarga dengan Lansia di Panti Sosial Tresna Werdha. Fakultas Kedokteran Ilmu Kesehatan UIN Alauddin Makassar.

Wood, A. M., Maltby, J., Stewart, N., Linley, P. A., \& Joseph, S. (2008). A Social-Cognitive Model of Trait and State Levels of Gratitude. Emotion, 8(2), 281-290. https://doi.org/10.1037/1528-3542.8.2.281.

Woodford, M. R., Kulick, A., Sinco, B. R., \& Hong, J. S. un. (2014). Contemporary heterosexism on campus and psychological distress among LGBQ students: the mediating role of self-acceptance. The American Journal of Orthopsychiatry, 84(5), 519-529. https://doi.org/10.1037/ort0000015. 